\title{
Alpha-Adrenoceptors in the Developing Kidney
}

\author{
ROBIN A. FELDER, ${ }^{(36)}$ JUAN C. PELAYO, PHILIP L. CALCAGNO, GILBERT M. EISNER, AND \\ PEDRO A. JOSE \\ Departments of Pediatrics, Physiology, and Biophysics and Medicine, Georgetown University Medical Center \\ Washington, D.C., USA
}

\section{Summary}

The maturation of renal alpha-adrenoceptors was investigated in dogs. Alpha-adrenoceptors were characterized by radioligand binding using the alpha-1-adrenergic antagonist, $\left[{ }^{3} \mathrm{H}\right]-\mathrm{WB}-4101$. In renal plasma membranes obtained from the outer cortex of neonates, the binding of the ligand was rapid, reversible, of high affinity, saturable, and stereoselective. The competition studies with adrenergic agonists and antagonists were indicative of alphareceptors. In puppies less than 1-w-old, the binding affinity of $\left[{ }^{3} \mathbf{H}\right]$ -WB-4101 $\left(K_{d}=0.638 \pm 0.17 \mathrm{nM}\right)$ was greater than 3-5 week-old puppies $\left(K_{d} 1.573 \pm 0.315 \mathrm{~nm}\right) ;(P<0.05)$, but receptor number was similar (63.75 \pm 19.1 versus $79.10 \pm 5.99 \mathrm{fmole} / \mathrm{mg}$ protein). No consistent specific binding could be demonstrated in plasma membranes obtained from inner cortex or medulla. In the adult dog, no consistent specific binding could be demonstrated for plasma membranes obtained from any region of the kidney. These studies indicate that during maturation there is a decrease in alpha-adrenoceptor density and affinity in membranes from the outer cortex of the kidney.

Recent studies have suggested that renal tubular sodium reabsorption may be modulated by renal nerve activity $(4,5,7,9,27)$. The kidney is richly innervated by adrenergic nerves and the presence of dopamine- and norepinephrine-containing nerves have been demonstrated $(1,2,10)$. The adrenergic nerves have been shown to be in direct contact with basement membrane of the proximal and distal tubules (1). Renal denervation decreases (4) and renal nerve stimulation increases (3) tubular sodium reabsorption. Several pathophysiologic conditions (denervation, salt loading) have been shown to alter norepinephrine and epinephrine levels in the kidney (22). In the rat (24) and dog (33) changes in sodium reabsorption have been related to alterations in alpha-adrenergic activity. In the isolated tubules of rabbits (5, 16) and mouse (26) however, increased sodium and chloride reabsorption $(5,16)$ in the proximal convoluted tubule, the thick ascending limb of Henle and the collecting duct followed administration of isoproterenol, a beta-adrenergic agonist. In addition, Bello-Reuss (5) showed that the increase in fluid (and presumably sodium) reabsorption in the proximal convoluted tubule induced by norepinephrine can be blocked by propranolol, a beta-adrenergic antagonist, but not by phenoxybenzamine, an alpha-adrenergic antagonist; thus, at least in the rabbit and mouse, betaadrenergic stimulation increases fluid transport. Dopamine, on the other hand, has been shown to decrease sodium reabsorption beyond the superficial distal tubule (25).

Recently, specific adrenergic and dopaminergic receptors have been described in the kidney in several animal species $(11,12,17$, $18,20,21,31)$. But no studies have characterized renal tubular alpha-adrenergic receptors in the dog, the species in which much of the physiologic data has been acquired. In order to understand further the role of alpha-adrenergic receptors in the canine kidney, we devised experiments to characterize alpha adrenergic receptors in renal tubular plasma membranes in the maturing and adult dog.

\section{MATERIALS AND METHODS}

Adult mongrel dogs or neonatal pupplies of either sex were anesthetized with pentobarbital. The kidneys were removed and placed in ice cold buffer containing $0.25 \mathrm{M}$ sucrose, $5 \mathrm{mM}$ Tris$\mathrm{Cl}, 10 \mathrm{mM} \mathrm{MgCl}_{2}, \mathrm{pH} 7.5$ at $4^{\circ} \mathrm{C}$. The kidneys were decapsulated and divided into an outer cortex, inner cortex and medulla as previously described from this laboratory (21). Partially purified plasma membranes were prepared according to the method of Fitzpatrick (13). To determine that this method is applicable to the puppy as well as the adult we determined the specific activity of the basolateral membrane marker Na-K-ATPase in crude and partially purified plasma membranes in 1-2-wk, 3-5-wk-old pupplies and adult dogs using the method of Jorgenson et al. (19). In addition, electron microscopic features of these membranes were consistent for basolateral membranes.

Binding studies. All studies were performed in triplicate. The incubation buffer consisted of $50 \mathrm{mM}$ Tris-Cl, $10 \mathrm{mM} \mathrm{MgCl}_{2}$ and final incubation volume was $400 \mu$ liters. Alpha-adrenergic receptors were assayed using the ligand $\left[{ }^{3} \mathrm{H}\right]-\mathrm{WB}-4101$ [2, 6-dimethoxyphenoxy ethyl amino methyl-1, 4 benzodioxane, 2-phenoxy 3$\left.{ }^{3} \mathrm{H}-(\mathrm{N})\right]$, an alpha-1, adrenergic antagonist $(15,30)$. For the characterization of alpha-receptors, the membrane preparation $(0.2-$ $1.8 \mathrm{mg}$ protein $/ \mathrm{ml}$ with sodium metabisulfite $2 \mu \mathrm{g} / \mathrm{ml}$ ) was incubated at $23^{\circ} \mathrm{C}$ for $10 \mathrm{~min}$ with $0.5-5 \mathrm{nM}$ concentrations of the ligand $\left[{ }^{3} \mathrm{H}\right]-$ WB-4101 (New England Nuclear, MA) with or without unlabeled $\mathrm{L}$-norepinephrine $(100 \mu \mathrm{M}$, final concentration) (32). After the incubation, the reaction mixture was rapidly filtered (GFC Whatman) under vacuum. The filters were air dried overnight and counted in $5 \mathrm{ml}$ of scintillation fluid in a beta-scintillation counter with an efficiency of $30 \%$. Because alpha-adrenoceptors have been described previously in rat kidney $(20,30,32)$, renal tissue from rats was prepared and studied in identical fashion as the dog kidney to serve as a reference.

Association kinetics were studied in membrane preparations (1 $\mathrm{mg} / \mathrm{ml}$ ) using $5 \mathrm{nM}\left[{ }^{3} \mathrm{H}\right]-$ WB-4101. After a 2-min equilibration period, studies were started by the addition of the ligand into the incubation mixture and the binding was assessed at periodic intervals for at least $30 \mathrm{~min}$. Nonspecific binding was assessed by the addition of $100 \mu \mathrm{M}$ L-norepinephrine. Dissociation kinetics were studied by the addition of $100 \mu \mathrm{M}_{\mathrm{L} \text {-norepinephrine to the }}$ incubation mixture of membrane and radioligand that has been incubated for $10 \mathrm{~min}$. Binding was assessed periodically for at least $30 \mathrm{~min}$ after the addition of L-norepinephrine. Additional kinetics were done using 0.5-1 nM $\left[{ }^{3} \mathrm{H}\right]$-prazosin, an alpha-1adrenoceptor specific antagonist; $10 \mu \mathrm{M}$ phentolamine was used to determine nonspecific binding.

Linearity of ligand binding to renal plasma membranes was assessed by determining specific binding with varying concentrations of membrane protein. Competition studies were also performed in which varying concentrations of adrenergic agonists and antagonists were added to the incubation mixture as indicated. Stereospecificity was also studied using $D$ and L-norepinephrine.

Calculations. Maximum receptor density $\left(B_{\max }\right)$ and dissociation constant $\left(\mathrm{K}_{\mathrm{d}}\right)$ were calculated from Scatchard plots (29). Inhibition constants $\left(\mathbf{K}_{\mathbf{i}}\right)$ were calculated according to Cheng and Prusoff $(8)$. 
The binding of the radioligand alone to the membrane was considered to be total binding. Binding in the presence of $100 \mu \mathrm{M}$ L-norepinephrine was considered nonspecific binding. Specific binding was the difference between total and nonspecific binding. Results are given as mean \pm standard error $(M \pm$ S.E.). Statistical evaluation was performed using the Student's $t$ test. A $P$ value of $<0.05$ was accepted as significant.

\section{RESULTS}

Membrane characteristics. Figure 1 and Figure 2 show membrane protein recovery and enrichment of $\mathrm{Na}-\mathrm{K}$-ATPase activity in renal outer cortex, inner cortex, and medulla in puppies and adult dogs. The protein recovery was similar in all regions and all age groups studied. Thus valid comparisons can be made among groups using this method of membrane preparation. The degree of enrichment (crude to partially purified membrane) in renal outer cortex, inner cortex, and medulla was also similar in all age groups studied. The degree of enrichment is comparable to those originally reported by Fitzpatrick (13) for adult animals.

Identification of alpha-adrenergic receptors. Binding kinetics. Specific $\left[{ }^{3} \mathrm{H}\right]-\mathrm{WB}-4101(1 \mathrm{nM})$ and $\left[{ }^{3} \mathrm{H}\right]$-prazosin $(1 \mathrm{nM})$ binding to partially purified cortical membranes reached steady state after $15 \mathrm{~min}$ and was stable for as long as $60 \mathrm{~min}$ (Fig. 3). The observed forward rate constant $\left(\mathrm{K}_{\text {obs }}\right)$ was $1.692 \cdot 10^{-3} \cdot \mathrm{sec}^{-1}$ giving a second order rate constant $\left(\mathrm{K}_{\mathrm{i}}\right)$ of $7.15 \cdot 10^{5} \mathrm{M}^{-1} \cdot \mathrm{sec}^{-1}$. At equilibrium the addition of $100 \mu \mathrm{M}$ phentolamine resulted in prompt dissociation of the radioligand (Fig. 4). There was an initial rapid loss (25\% of the binding) followed by a slower decay. This is similar to that previously reported by Newman (23) et al. using $\left[{ }^{3} \mathrm{H}\right]$-dihydroergocryptine as the radioligand. The first order rate constant $\left(\mathrm{k}_{-1}\right)$ for the reversal of specific binding $(0.68 \mathrm{nM})$ was $1.227 \cdot 10^{-3}$. $\mathrm{sec}^{-1}$. The $\mathrm{K}_{\mathrm{d}}$ calculated from the reverse rate constant was 1.7 $\mathrm{nM}$, similar to that obtained in the saturation studies.

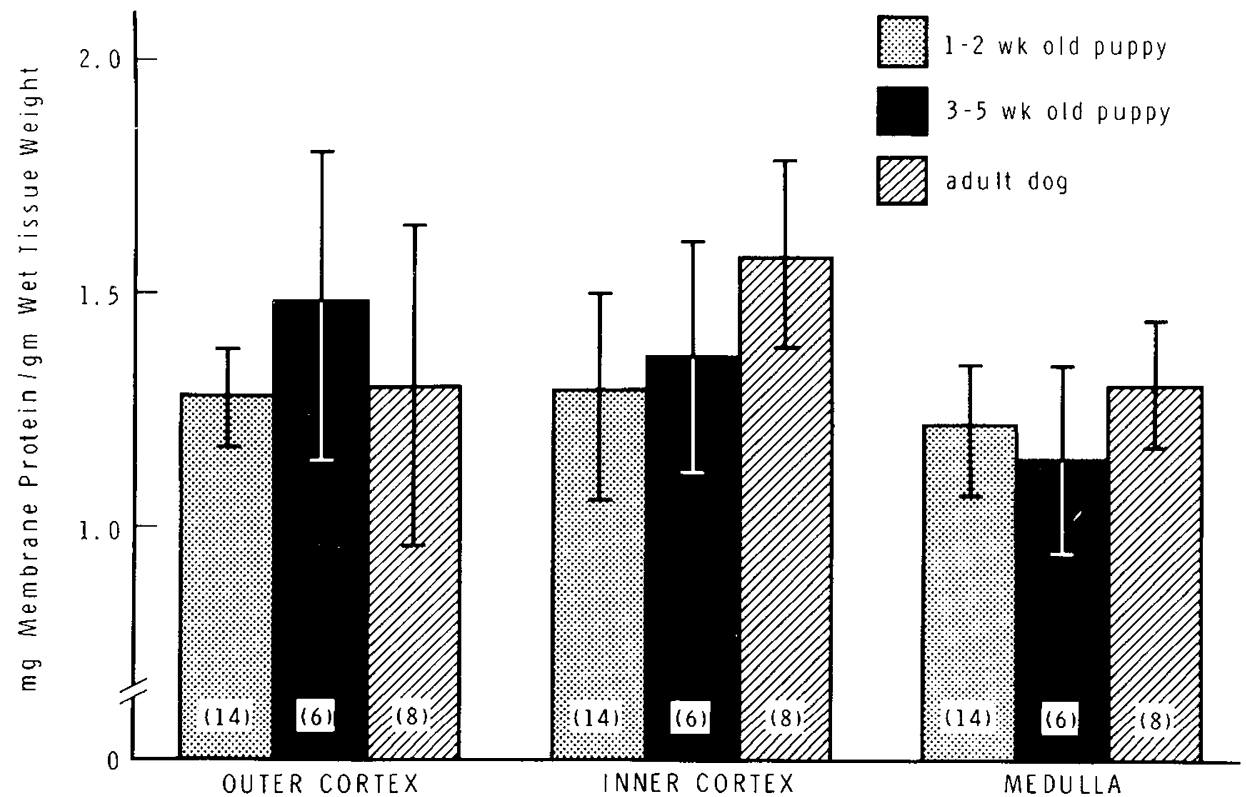

Fig. 1. Membrane protein recovery (mg membrane/g wet tissue weight) in renal outer cortex inner cortex and medulla in 1-2 wk, 3-5 wk, and adult dogs.

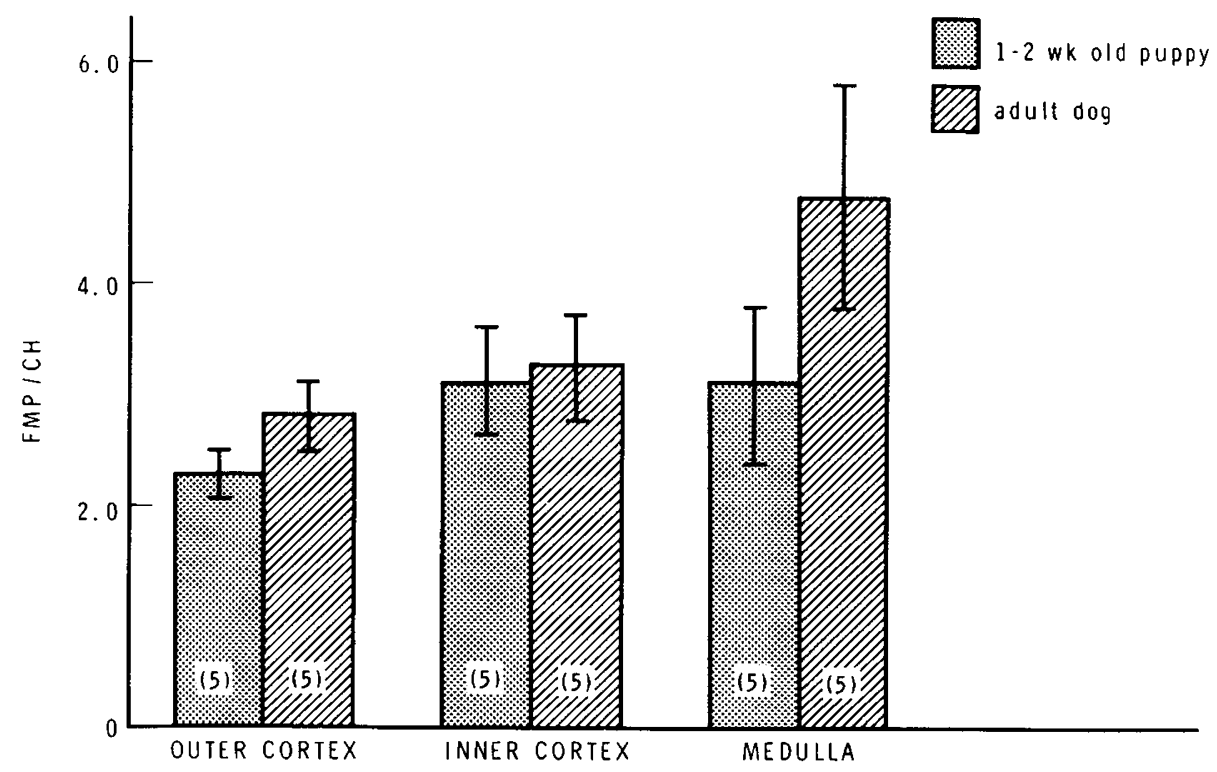

Fig. 2. Increase in Na-K-ATPase activity from crude homogenates $(\mathrm{CH})$ to final membrane preparation (FMP) in 1-2-week-old puppy and adult dog. 
Identification of alpha-adrenergic receptors. Saturability and affinity of $[3 \mathrm{H}]-W B-4101$ binding sites. In partially purified rat plasma membranes, the reference tissue, the specific binding of $\left[{ }^{3} \mathrm{H}\right]-\mathrm{WB}-4101$ was approximately $50 \%$. In Wistar rats $(N=3)$, $\mathrm{B}_{\max }$ was $147 \pm 10.8 \mathrm{fmole} / \mathrm{mg}$ protein and the $K_{d}$ was $1.16 \pm 0.88$ nM. Partially purified plasma membranes from adult dog kidneys did not show any consistent specific binding on outer cortex, inner cortex, medulla, or whole kidney.

In puppies, in contrast to the adult dog studies, we found that specific binding of $\left[{ }^{3} \mathrm{H}\right]-W B-4101$ occurred in outer cortical membranes but not in inner cortex or medulla and was approximately $30 \%$ of the total binding. Using prazosin $10^{-5} \mathrm{M}$ to determine nonspecific binding, the competition studies were consistent for alpha-receptors. The potency sequence for agonists was epinephrine $>$ norepinephrine $>$ isoproterenol. The $K_{i}$ for epinephrine was $72 \mathrm{nM}$, norepinephrine was $480 \mathrm{nM}$ and isoproterenol 4700 nM. The potency sequence for antagonists was yohimbine $>$ prazosin $>$ propranolol. The stereoisomer $\mathrm{l}$-norepinephrine was more effective in competing with the binding of $\left[{ }^{3} \mathrm{H}\right]-\mathrm{WB}-4101$ than D-norepinephrine $\left(\mathrm{K}_{\mathrm{i}}=480,000 \mathrm{nM}\right)(1000$-fold $)$. The $\mathrm{K}_{\mathrm{i}}$ for yohimbine was $0.37 \mathrm{nM}$, prazosin was $1.83 \mathrm{nM}$ and propranolol was $620 \mathrm{nM}$.

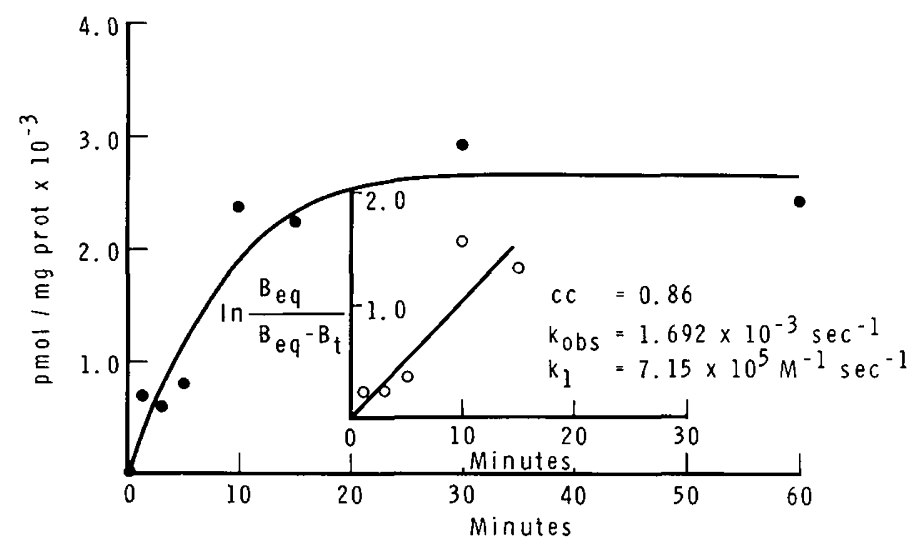

Fig. 3. Specific $\left[{ }^{3} \mathrm{H}\right]-W B-4101$ or $\left[{ }^{3} \mathrm{H}\right]-$ prazosin binding to partially purified cortical tubular membranes from 3-wk-old puppy. The radioligand (concentration $0.5-1 \mathrm{nM}$ ) was incubated with tubular membranes $(1.5 \mathrm{mg} / \mathrm{ml})$ for the times indicated. Each value is the mean of triplicate determinations. The inset is the linear transformation of the same data. See text for abbreviations.
Analysis of the data from Scatchard plots revealed a single class of receptors. Figure 5 shows a representative Scatchard plot of specifically bound radioligand in cortical membranes in 1-wk-old puppies. The $B_{\max }$ and $K_{d}$ in puppies are shown in Table 1 . The $\mathrm{K}_{\mathrm{d}}$ in outer cortical membranes from puppies less than 1-wk-old was significantly less than that found in 3-5-wk-old puppies. The $B_{\max }$ did not change with age.

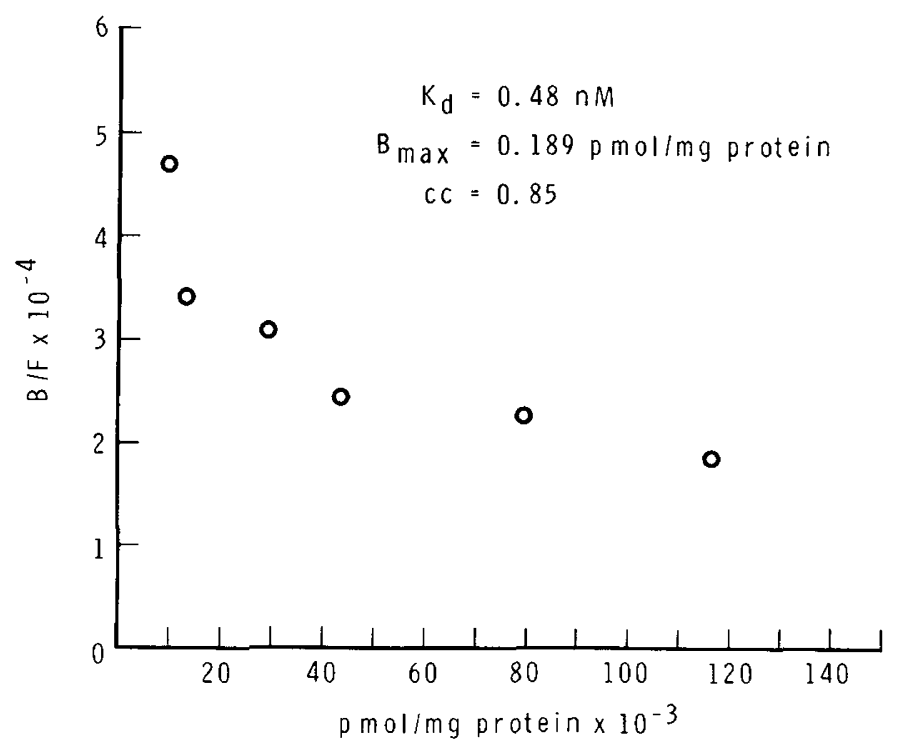

Fig. 5. Scatchard analysis of specific $\left[{ }^{3} \mathrm{H}\right]-\mathrm{WB}-4101$ binding to partially purified renal cortical membranes. [ $\left.{ }^{3} \mathrm{H}\right]-$ WB-4101 concentration ranged from $0.5-5 \mathrm{nM}$.

Table 1. Alpha adrenergic receptors in canine renal outer cortical membranes from puppies and adult dogs

\begin{tabular}{lccc}
\hline \multicolumn{1}{c}{ Age } & $n$ & $\mathrm{~K}_{\mathrm{d}}(\mathrm{nM})$ & $\mathrm{B}_{\max }$ (fmole/mg protein) \\
\hline $1 \mathrm{wk}^{\prime}$ & 8 & $0.638 \pm 0.170^{2}$ & $63.75 \pm 19.1$ \\
$3-5 \mathrm{wk}$ & 8 & $1.573 \pm 0.315$ & $79.10 \pm 5.99$ \\
Adult & 3 & 0 & 0 \\
\hline
\end{tabular}

'Kidneys from 2-3 puppies were pooled for each experiment.

${ }^{2} P<0.01$. In 1 -week-old puppies, the correlation coefficient between $\mathrm{K}_{\mathrm{d}}$ and age in days was $0.625(P<0.10>0.05$, two-tail test $)$. In older puppies, the correlation coefficient between $K_{d}$ and age in days was 0.22 .

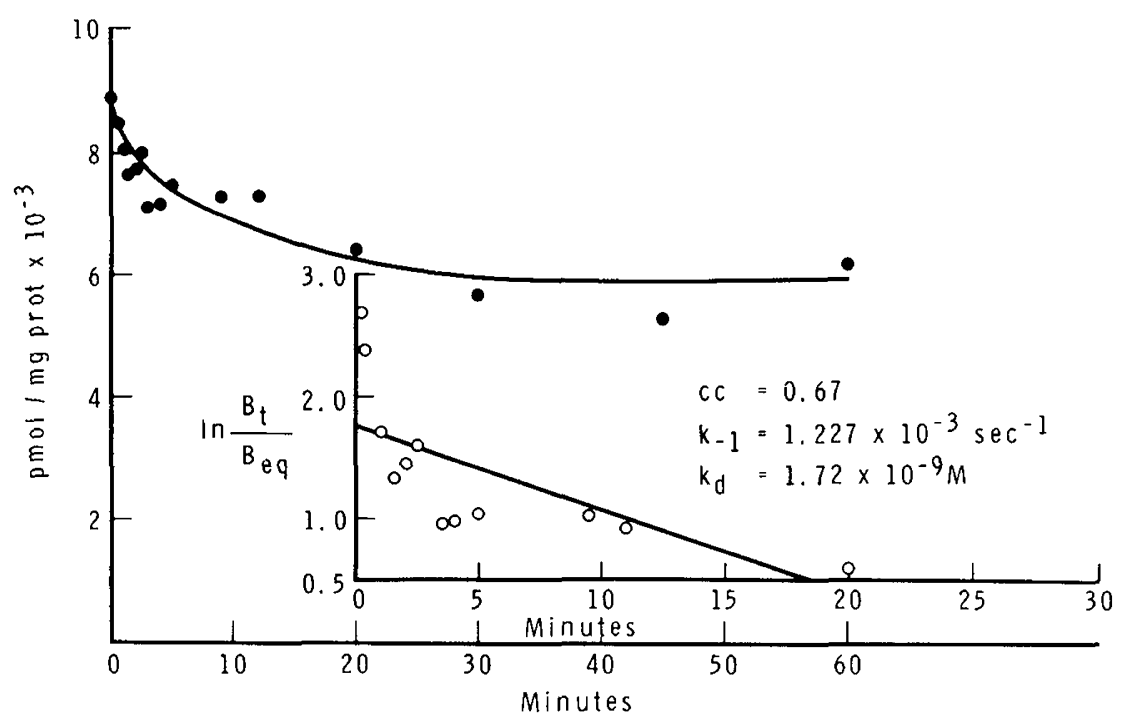

Fig. 4. Reversibility of $\left[{ }^{3} \mathrm{H}\right]$-prazosin binding to renal cortical membranes from 3-wk-old puppy. Partially purified membranes were incubated with $0.68 \mathrm{nM}\left[{ }^{3} \mathrm{H}\right]$-prazosin for $20 \mathrm{~min}$ after which time $100 \mu \mathrm{M}$ phentolamine was added. The time of phentolamine addition was at time 0 as indicated. See text for abbreviations. 


\section{DISCUSSION}

In adult dogs, specific binding to $\left[{ }^{3} \mathrm{H}\right]-$ WB-4101 could not be consistently demonstrated in partially purified plasma membranes obtained from cortical or medullary regions. This probably was not a methodologic problem as the specific binding, $B_{\max }$ and $\mathrm{K}_{\mathrm{d}}$ obtained with rat kidneys, the reference tissue, were comparable to the values reported by others in the rat $(20,30,32)$. Further, the observation that alpha-adrenoceptors are demonstrable in puppy kidneys and that beta-adrenoceptors are demonstrable in the kidneys of adult dogs (21) provides further evidence that the technique is not at fault. It is possible, however, that the assay conditions may not be sufficiently sensitive to detect minute quantities of adrenoceptors in dog tubules under basal conditions or that only under stress could one detect alpha-adrenoceptors in adult dog tubules (33).

In puppies, the binding of $\left[{ }^{3} \mathrm{H}\right]-\mathrm{WB}-4101$ to partially purified outer cortical membranes was rapid, reversible, saturable, of high affinity, and stereoselective. The competition studies were also suggestive of alpha-adrenoceptors. Although the $B_{\max }$ did not change with age, the $K_{d}$ increased with age, indicating a decreasing affinity for alpha-receptors with maturation.

It is now established that there are at least two types of alphaadrenoceptors (6). Alpha-1-adrenoceptors are usually present postsynaptically in noradrenergically innervated smooth muscles. Alpha-2-receptors are present in adrenergic nerve terminals and have also been noted postsynaptically in some tissues including guinea pig and rat kidney $(6,18,20)$. Although we did not attempt to determine the type of alpha-adrenoceptor in brain, $\left[{ }^{3} \mathrm{H}\right]-\mathrm{WB}$ 4101 binds preferentially to alpha-1-adrenoceptors (32). In some peripheral tissues, however, $\left[{ }^{3} \mathrm{H}\right]-\mathrm{WB}-4101$ binds equally well to alpha-1- and alpha-2-adrenoceptors (15). In our competition studies, yohimbine, an alpha-2-antagonist $(18,20)$ was equal or more potent than prazosin in competing with the binding of $\left[{ }^{3} \mathrm{H}\right]-\mathrm{WB}$ 4101; thus, these studies suggest that the newborn kidney is rich in alpha-1- and alpha-2-adrenoceptors.

\section{REFERENCES AND NOTES}

1. Barajas, L.: Innervation of renal cortex. Fed. Proc., 37: 1192 (1978).

2. Barajas, L. and Wang, P.: Localization of tritiated norepinephrine in renal arteriolar nerves. Anat. Rec., 195: 525 (1979).

3. Bello-Reuss, E., Trevino, D. L., and Gottschalk, C. W.: Effect of renal sympathetic nerve stimulation on proximal water and sodium reabsorption. J. Clin. Invest., 57: 1104 (1976).

4. Bello-Reuss, E., Pastoriza-Munoz, E., and Colindres, R. E.: Acute unilateral denervation in rats with extracellular volume expansion. Am. J. Physiol., 232. F26 (1977).

5. Bello-Reuss, E.: Effects of catecholamines on fluid reabsorption by the isolated proximal convoluted tubule. Am. J. Physiol., 238: F347 (1980).

6. Berthelsen, S. and Pettinger, W. A.: A functional basis for classification of alpha adrenergic receptors. Life Sci., 21: 595 (1977).

7. Besarab, A.. Silva, P., Lansberg, L., and Epstein, F. H.: Effect of catecholamines on tubular function in the isolated rat kidney. Am. J. Physiol., 233: F39 (1977)

8. Cheng, Y, and Prusoff, W.: Relationship between the inhibition constant $\left(K_{j}\right)$ and the concentration of inhibitor which causes $50 \%$ inhibition $\left(\mathrm{IC}_{\mathrm{in}}\right)$ of an enzymatic reaction. Biochem. Pharmacol., 22: 3099 (1973).

9. DiBona, G. F.: Neurogenic regulation of renal tubular sodium reabsorption. Am. J. Physiol., 233: F73 (1977).

10. Dinnerstein, R. J., Vannice, J., Henderson, R. C., Roth, L. J., Goldberg, L. I., and Hoffman, P. C.: Histofluorescence techniques provide evidence for dopamine containing neuronal elements in canine kidney. Science, 205: 497 (1979).

11: Felder, R., Pelayo, J., Blecher, M., Calcagno, P., Eisner, G., and Jose, P.: Multiple renal dopamine receptor. (Abstract) Clin. Res., 29: 462A (1981)

12. Felder, R., Schoelkopf, L., Pelayoa, J., Blecher, M., Calcagno, P., Eisner, G., and Jose, P.: Adrenergic and dopaminergic receptors in glomeruli and cortical tubules. (Abstract) Proc. Am. Soc. Nephrol. p. 132A, Wash., D.C. (1980).

13. Fitzpatrick, D. F.: Characterization of plasma membrane proteins in mammalian kidney. I. Preparation of a membrane fraction and separation of protein. J. Biol. Chem., 244: 3561 (1969).

14. Goldsmith, D. I., Drukker, A., Blaufox, M. D., Edelmann, C. M., and Spitzer, A.: Hemodynamic and excretory response of the neonatal canine kidney to acute volume expansion. Am. J. Physiol., 237: F382 (1979).

15. Hoffmann, B. B. and Lefkowitz, R. J.: Alpha adrenergic receptor subtypes. N. Engl. J. Med., 302: 1390 (1980).

16. Iino, Y. and Brenner, B. M.: Stimulation of chloride transport by isoproterenol in isolated cortical collecting tubule. (Abstract) Kidney Int., 16: 821 (1979).

17. Insel, P. A. and Snavely, M. D.: Catecholamines and the kidney: receptors and renal function. Ann. Rev. Physiol., 43: 625 (1981).

18. Jarrot, B. A., Louis, W. J., and Summers, R. J.: The characteristics of ${ }^{\text {is }} \mathrm{H}$ clonidine binding to an alpha adrenoceptor in membranes from guinea pig kidney. $\mathrm{Br}$. J. Pharmacol., 65: 663 (1979).

19. Jorgenson, P. L.: Methods in Enzymology. 32, p. 277. Colwick, S. P. and Kaplan, V. O., Eds. Academic Press, N.Y. (1974).

20. McPherson, G. A. and Summers, R. J.: ${ }^{3} \mathrm{H}$-prazosin and ${ }^{3} \mathrm{H}$-clonidine binding to alpha adrenoceptors in membranes prepared from regions of rat kidney. $\boldsymbol{J}$. Pharm. Pharmacol., 33: 189 (1981).

21. Montgomery, S., Jose, P.. Spiro. P., Slotkoff, L., and Eisner, G.: Regional differences in the binding affinities of B-adrenergic receptors in the canine kidney cortex. Proc. Soc. Exptl. Biol. Med., 162: 260 (1981).

22. Morgunov, N. and Baines, A. D.: Renal nerves and catecholamine excretion. Am. J. Physiol., 240: F75 (1981)

23. Newman, K. D., Williams, L. T., Bishopric, N. H., and Lefkowitz, R. J.: Identification of alpha-adrenergic receptors in human platelets by $(3 \mathrm{H})$ dihydroergocryptine binding. J. Clin. Invest., 61: 395 (1978).

24. Pastoriza, E.: Effect of alpha-adrenergic stimulation and blockade in the proximal convoluted tubule of the rat. (Abstract). Proc. Am. Soc. Nephrol. p. 61A, Boston, MA. (1979).

25. Pelayo, J. C., Eisner, G. M., and Jose, P. A.: The effects of dopamine blockade on renal sodium excretion. Pediatr. Res., (Abstract), 7: 989 (1980).

26. Polhemus, R. E. and Hall, D. A.: Effect of catecholamines on the potential difference and chloride efflux in the mouse ascending limb of Henle. (Abstract) Proc. Am. Soc. Nephrol. p. 146A, Wash. D.C. (1980).

27. Prosnitz, E. H. and DiBona, G. F.: Effect of decreased sympathetic nerve activity on renal tubular reabsorption. Am. J. Physiol., 235: F557 (1978).

28. Sanchez, A. and Pettinger, W. A.: Dietary sodium regulation of blood pressure and renal alpha 1 and alpha 2 receptors in WKY and SHR rats. Life Sci., 29: 2795 (1981).

29. Scatchard, G.: The attractions of proteins for small molecules and ions. N. Y. Acad. Sci.., 51: 660 (1949).

30. Schmitz, J. M., Graham, R. M., and Pettinger, W. A.: Renal alpha-1 and alpha2 adrenergic receptors: biochemical and pharmacological correlations. J. Pharmacol. Exp. Ther., 219(2): 400 (1981).

31. Scott. C. K. and Vanderwende, C.: The identification of ${ }^{3} \mathrm{H}$-apomorphine binding sites in dog renal cortex-membrane preparations. (Abstract) Fed. Proc., 38: 1007 (1980).

32. U'Pritchard, D. G. and Snyder, S.: Distinct alpha adrenergic receptors differentiated by binding and physiological relationships. Life Sci., 24: 79 (1979).

33. Zambraski, E. J., DiBona, G. F., and Kaloyanides, G. J.: Effect of sympathetic blocking agents on the natriuresis of reflex renal nerve. J. Pharmacol. Exp. Ther., 198: 464 (1976).

34. Thank you to Mrs. Carolyn Patterson for her secretarial assistance.

35. This study was supported in part by grants HL 23081-03 and HL 06213 (19771982).

36. Request for reprints should be directed to Robin A. Felder, Georgetown University Medical Center, Wash. D.C. 20007

37. Received for publication June 26, 1981.

38. Accepted for publication September 9, 1982. 